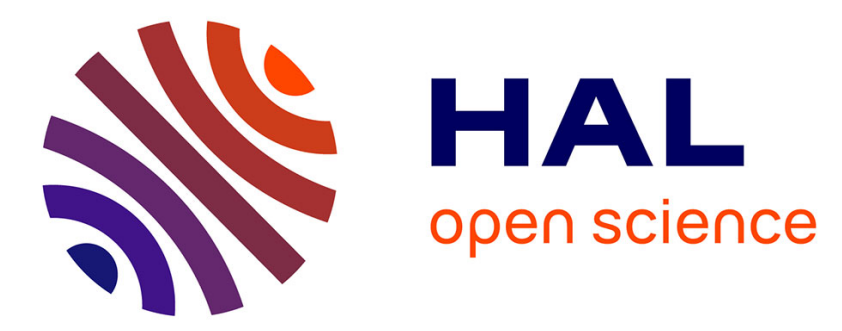

\title{
Echinococcus multilocularis in Svalbard, Norway: Microsatellite genotyping to investigate the origin of a highly focal contamination.
}

J. Knapp, S. Staebler, J. M. Bart, A. Stien, N. G. Yoccoz, C. Drögemüller, B. Gottstein, P. Deplazes

\section{To cite this version:}

J. Knapp, S. Staebler, J. M. Bart, A. Stien, N. G. Yoccoz, et al.. Echinococcus multilocularis in Svalbard, Norway: Microsatellite genotyping to investigate the origin of a highly focal contamination.. Infection, Genetics and Evolution, 2012, epub ahead of print. 10.1016/j.meegid.2012.03.008 . hal00686742

\section{HAL Id: hal-00686742 \\ https://hal.science/hal-00686742}

Submitted on 11 Apr 2012

HAL is a multi-disciplinary open access archive for the deposit and dissemination of scientific research documents, whether they are published or not. The documents may come from teaching and research institutions in France or abroad, or from public or private research centers.
L'archive ouverte pluridisciplinaire HAL, est destinée au dépôt et à la diffusion de documents scientifiques de niveau recherche, publiés ou non, émanant des établissements d'enseignement et de recherche français ou étrangers, des laboratoires publics ou privés. 


\section{Title}

2 Echinococcus multilocularis in Svalbard, Norway: microsatellite genotyping to investigate the

3 origin of a highly focal contamination.

4

5

6

7 J. Knapp ${ }^{\text {a, }}$, S. Staebler ${ }^{\text {b }}$, J. M. Bart ${ }^{\text {c }}$, A. Stien ${ }^{\text {d }}$, N. G. Yoccoz ${ }^{\text {d,e }}$, C. Drögemüller ${ }^{\text {f }}$, B.

8 Gottstein $^{\mathrm{g}}, \mathrm{P}$. Deplazes ${ }^{\mathrm{b}}$

\section{Author affiliations}

a Laboratory of Chrono-environment, UMR 6249, University of Franche-Comté, Besançon, France

${ }^{\mathrm{b}}$ Institute of Parasitology University of Zürich, Zürich, Switzerland

${ }^{\mathrm{c}}$ Centro Nacional de Medicina Tropical, Madrid, Spain

${ }^{\mathrm{d}}$ NINA Troms $\phi$, Fram - High North Research Centre for Climate and the Environment, 9296 Troms $\phi$, Norway

${ }^{\mathrm{e}}$ Department of Arctic and Marine Biology, University of Troms $\phi$, Troms $\phi$, Norway

${ }^{\mathrm{f}}$ Institute of Genetics, University of Bern, Bern, Switzerland

${ }^{\mathrm{g}}$ Institute of Parasitology, University of Bern, Bern, Switzerland

* Corresponding author. Tel.: +33 36308 2274; fax: +33 363082232

E-mail address: jenny.knapp@ univ-fcomte.fr (J. Knapp) 


\section{ABSTRACT}

Echinococcus multilocularis is a threatening cestode involved in the human alveolar echinococcosis. The parasite, mainly described in temperate regions of the northern hemisphere was described for the first time in 1999 in the High Arctic Svalbard archipelago, Norway. The origin of this contamination could be due to an anthropogenic introduction from mainland Europe by domestic dogs or with the introduction of the sibling vole, perhaps from mainland Russia (St Petersburg area), or with roaming Arctic foxes, known as the main definitive host of the parasite in Arctic regions. The genetic diversity of E. multilocularis in Svalbard was investigated here for the first time by genotyping using EmsB microsatellite and compared to other genotyped populations in the main worldwide endemic areas. We found low polymorphism amongst the 27 metacestode isolates from sibling voles trapped in the core of the distribution area of the vole on Svalbard. E. mutilocularis arctic populations, using the Arctic fox as the definitive host, were genetically separated from European temperate populations that use the red fox, but closely related to Saint Lawrence Island samples from Alaska. The result is inconsistent with the hypothesis of an anthropogenic introduction from mainland Europe, but can be seen as consistent with the hypothesis that Arctic foxes introduced E. multilocularis to Svalbard.

\section{Keywords}

\section{Echinococcus multilocularis}

Microsatellite EmsB

Parasite dynamics

Arctic fox

Sibling vole

\section{Introduction}

The taeniid parasite Echinococcus multilocularis is the causative agent of Alveolar Echinococcosis (AE), one of the most health-threatening helminthic zoonosis occurring on the 
Northern hemisphere (Fig. 1). The parasite, mostly described in Europe, some parts of North America, and Asia (Vuitton et al., 2003), requires two mammalian hosts to achieve its life cycle: a carnivore definitive host such as the red fox (Vulpes vulpes Linnaeus 1758), or the Arctic fox (Vulpes lagopus Linnaeus 1758) in Northern latitudes and a rodent intermediate host, of which many species appear susceptible (Rausch, 1995; Vuitton et al., 2003). The recent establishment of the parasite transmission on the Norwegian Arctic archipelago Svalbard, (Henttonen et al., 2001) was made possible by the anthropogenic introduction of the only available intermediate host species to the islands, the sibling vole (Microtus levis Miller 1908), certainly from mainland Russia. This introduction probably occurred in the first half of the 20th century, with mining and maritime activities (Henttonen et al., 2001). The core rodent habitat on Svalbard is along an $8 \mathrm{~km}$ stretch of bird cliffs along the coast in the Grumant area, $10 \mathrm{~km}$ west of the main Norwegian settlement, Longyearbyen $\left(78^{\circ} 13^{\prime} \mathrm{N}, 15^{\circ}\right.$ 38’ E) (Fuglei et al., 2008; Stien et al., 2010). In the Grumant area E. multilocularis has been found with high prevalence in the rodents (26\%; 59 infected of 224 trapped rodents (Henttonen et al., 2001)), the Arctic foxes (35\%; 13 infected of 37 trapped foxes (Stien et al., 2010)), and in fox faeces (60\%; 135 infected of 224 fox faeces sampled (Fuglei et al., 2008)). While the introduction of the intermediate host was a prerequisite for the establishment of the parasite life-cycle, the oncoming of the parasite has been suggested to be due to large scale roaming on sea ice by Arctic foxes between Svalbard and E. multilocularis-endemic areas in Siberia (Henttonen et al., 2001). An alternative hypothesis is the possible introduction of the parasite with the sibling voles, which are likely to originate from the St Petersburg area in Russia. Finally, a third alternative hypothesis is that the parasite has been anthropogenically introduced from mainland Europe, in association with the substantial movement of humans and possibly dogs between Europe and Svalbard due to tourism, mining and scientific explorations in the 20th century.

E. multilocularis present a genetic homogeneity with nuclear and mitochondrial targets (Haag et al., 1997), but fast evolution markers, such as the repeated microsatellite EmsB, are readily available to detect variations at regional and local scales (Bart et al., 2006; Knapp et al., 2007; Knapp et al., 2008). Recently, a European study has documented the presence of several EmsB profiles distributed in the historical endemic area in the European Alps with surprising patterns of genetic diversity and evidence for spread to peripheral regions as a mainlandisland system (Knapp et al., 2009). From this study, a catalogue of EmsB profiles, described in Europe and in some of the main worldwide endemic areas including China (Tibetan 
plateau), Alaska (Saint Lawrence Island) and Japan (Hokkaido), is now available and allows us to characterize the parasite diversity. Here we have tested whether E. multilocularis on Svalbard has been introduced from the European mainland by comparing the EmsB profiles of samples from Svalbard with samples from the European mainland. In addition we evaluate the genetic identity of the Svalbard samples in relation to the other endemic areas in the northern hemisphere with genetic samples available to improve our description of patterns in the genetic diversity of the parasite.

\section{Materials and methods}

\subsection{Samples collection and DNA extraction}

A sample collection of 27 metacestodes was constituted from sibling voles (Microtus levis) trapped in August 2004 - 2006 in the Grumant area (Stien et al., 2010) (Fig. 2). Total DNA was extracted from metacestode tissue or isolated protoscoleces (Stieger et al., 2002).

\subsection{Nuclear targets, PCR amplification and fragment size analyses}

PCR amplification was performed for the nuclear targets EmsB, as previously described (Bart et al., 2006) and for the partial sequences of the protein coding genes of ezrin-radixin-moesinlike protein $(E l p)$, calreticulin $(\mathrm{Cal})$ and thioredoxin peroxidase $(\mathrm{Th})$, as recommanded by authors (Saarma et al., 2009). The EmsB target was studied for the polymorphism of the tandemly repeated microsatellite by fragment size analysis, on 3730 ABI sequencer (Applied Biosystem, Foster City, CA) and analysed on GeneMapper 3.0. The amplified samples were compared with a worldwide E. multilocularis sample collection, containing aggregated samples (from fields about $500 \mathrm{~m}^{2}$ in Switzerland and $100 \mathrm{~m}^{2}$ in Alaska) (Knapp et al., 2007)) and non correlated isolates from Europe (Switzerland, Czech Republic, Slovakia, Austria, Germany, Netherlands, Poland and France; $n=42$ ), North America (St Lawrence Island, Alaska and Canada, $n=11$ ), China (Tibetan plateau; $n=5$ ) and Japan (Hokkaido; $n=6$ ). The available E. multilocularis samples closest to the putative starting point of the sibling voles introduced to Svalbard were the North-East Polish specimens $(900 \mathrm{~km}$ south of $\mathrm{St}$ Petersburg). Two E. granulosus sensu lato was chosen as outgroups (Knapp et al., 2007) and a hierarchical clustering analysis (HCA), using the Euclidean distance and the UPGMA 
method in the R software was performed. A genetic threshold previously described on the stability on time of EmsB profiles allowed us to discriminate similar and distinct isolates (Knapp et al., 2007). The nuclear targets elp (1023 bp), cal (1368 bp) and th (583 bp), previously sequenced for the currently described Echinococcus species (Saarma et al., 2009), were chosen to investigate the worldwide genetic diversity of the parasite. The targets were sequenced for E. multilocularis isolates from Central Europe (Switzerland), Canada (an isolate from a rodent, exact geographical position unknown), Alaska (St Lawrence Island) and Japan, and compared to one randomly chosen Svalbard sample using BioEdit (Hall, 1999).

\section{Results}

In comparison to referenced E. multilocularis sequences (GenBank Ref. FN582291; FR820773 to FR820783), 4 mutations were described on Elp and Th for the Svalbard isolate (none in Cal) (FR820594 to FR820596), two of these were common with the Canadian specimen and one was common with the European specimen (Table 1). However, this low genetic diversity did not allow us to conclude a divergence among the E. multilocularis samples. The pattern of the EmsB electrophoregram profiles were first compared to the others, and were found similar to Alaskan samples by the presence on the electrophoregram of a 209 bp fragment (Fig. 3(a)) never found in the other samples so far. From the HCA (Fig. 3(b)) performed by EmsB data computing, the European samples were clustered in a group, somewhat associated with the Chinese samples and distinct from the Japanese samples. The Svalbard samples were all clustered together, in the same group; the genetic distance amongst all the Svalbard samples was under the threshold of 0.08 (Fig 3(b)) and allowed us to considered them as identical to each other. Moreover they were closely related to St Lawrence Island samples from Alaska, and formed the most distant group from the other Eurasian samples (Fig. 3 (b)). These Arctic samples clustered clearly in a separate group from the samples from temperate Europe, China, Japan and Canada.

\section{Discussion}

In comparison with the high polymorphism of the EmsB target found in multiple European $E$. multilocularis populations, an extremely low diversity seemed to occur in the isolated Arctic islands of St Lawrence, Alaska (Knapp et al., 2007) and Svalbard. Such a pattern has previously been observed in samples from small areas such as a field in Fribourg 
(Switzerland) and by the Savoonga air-strip on St Lawrence (Alaska) (Knapp et al., 2007). These findings emphasize a putative clonal distribution of the parasite on restricted areas, as an expected result of an initial contamination by a small number of foxes (Knapp et al., 2007). In addition, the low genetic polymorphism of the parasite in the investigated Arctic sites could be linked to (i) the occurrence of one or few E. multilocularis populations in circumpolar areas, after a founder event in a mainland-island context, (ii) these islands could be considered as metapopulations connected by sea ice, explaining the genetic similarity between insular samples or (iii) in this context a low diversity of intermediate and definitive host species exists when compared to European sites. The Arctic fox appears as a genetically homogenous species, except for a few isolated islands not connected by sea ice in winter (Norén et al., 2011). From a co-evolution point of view, one could hypothesize that the parasite may evolve more slowly in an insular environment than in the temperate mainland situation where many species of potential intermediate host rodent species occur simultaneously. As such, these findings indicate particularities in the circumpolar $E$. multilocularis life cycle, which seems to have low or no connection with E. multilocularis life cycles from temperate regions.

Our microsatellite EmsB analysis suggests that Arctic E. multilocularis populations have a common history. Indeed, a high genetic similarity was observed between the geographically distant samples from Svalbard and Alaska, and a wide dissimilarity with the clustered European samples, even from North Europe was found (Fig. 3(b)). This may suggest an epidemiological connection between polar populations. Most likely, this could be due to the behavioral characteristics of the Arctic fox, a species with a circumpolar distribution and long distance movements (Norén et al., 2011). From our samples, we can reject the hypothesis of an anthropogenic introduction of E. multilocularis from mainland Europe, while the hypothesis of an Arctic fox driven immigration from Siberia to Svalbard is likely. Concerning the hypothesis of a strain coming from the Russian sibling vole we can speculate that the Russian E. multilocularis could be similar to North-East Europe as the Polish parasites were sampled $900 \mathrm{Km}$ from St Petersburg. However, more samples of E. multilocularis from Russia are needed to further evaluate this hypothesis.

\section{Acknowledgments}


182 We thank Prof. Henttonen for providing samples from Svalbard and Antti Lavikainen for the 183 sequence data.

184 This work was supported by the Swiss National Science Foundation (grant no. 1003A185 125990) and Research Council of Norway.

186

187 Dr. Knapp completed her PhD at the University of Franche-Comte and is a clinical research 188 engineer in the University hospital of Besançon, France. Her major research focus is the 189 molecular epidemiology of echinococcosis. 
192 Table and figure legends

193 Fig. 1. Worldwide dispersion of E. multilocularis (orange areas) and distribution of the world

194

195

196

197

198

199

200

201

202

203

204

205

206

207

208

209

210

211

212 collection samples, clustered by local position (black stars) studied for EmsB profiles. The exact geographical position of the Canadian sample is unknown (From (Eckert et al., 2011; Osterman Lind et al., 2011)).

Fig. 2. Map of Svalbard and the details of the Grumant area (dotted line) where the sibling voles (Microtus levis) infected by E. multilocularis were sampled in August 2004 - 2006.

Fig. 3 (a) EmsB electrophoregrams of an Alaskan sample (3AL-r), a Svalbard sample (Sval14-r), an Austrian sample (278A-F) and a German sample (101D-F), size in base pair. (b) E. multilocularis hierarchical clustering analysis, based on EmsB microsatellite results. The genetic threshold at 0.08 described similar and distinct EmsB profiles (for details on the construction see Knapp et al., 2007). The sample codes used are: Sval: Svalbard; AL: Alaska; CND: Canada; J: Japan; CH: Switzerland; CZ: Czech Rep., SK: Slovakia; A: Austria; D: Germany; H: Netherlands; PL: Poland; F: France; PRC: Peoples' Rep. of China; hosts codes: -r: rodent; -h: human; -m: monkey; -F: fox. Isolates 500AUB to 502AUB are one E. multilocularis strain maintained in vivo by several passages in Meriones unguiculatus; the grey scares represent the E. multilocularis regional groups; 116Eg (from Mauritanian camel) and 539Eg (from Algerian sheep) are E. granulosus outgroup controls. The approximately unbiased $P$ values (numbers on nodes, in percent) were calculated with a multiscale bootstrap resampling $(B=1000)$. 
214 Table 1: Comparison of the E. multilocularis Elp and Th gene fragments from different 215 origins.

\begin{tabular}{|c|c|c|c|c|}
\hline \multirow[t]{2}{*}{ E. multilocularis origin } & \multicolumn{3}{|c|}{$E / p(b p)$} & $T h(\mathrm{bp})$ \\
\hline & 323 & 459 & 631 & 328 \\
\hline Svalbard & C & $A$ & $\mathrm{~T}$ & C \\
\hline St Lawrence Island & $\mathrm{T}$ & C & C & $\mathrm{T}$ \\
\hline Canada & C & C & C & C \\
\hline Switzerland & $\mathrm{T}$ & C & C & C \\
\hline Hokkaido & $\mathrm{T}$ & C & C & $\mathrm{T}$ \\
\hline
\end{tabular}

216 


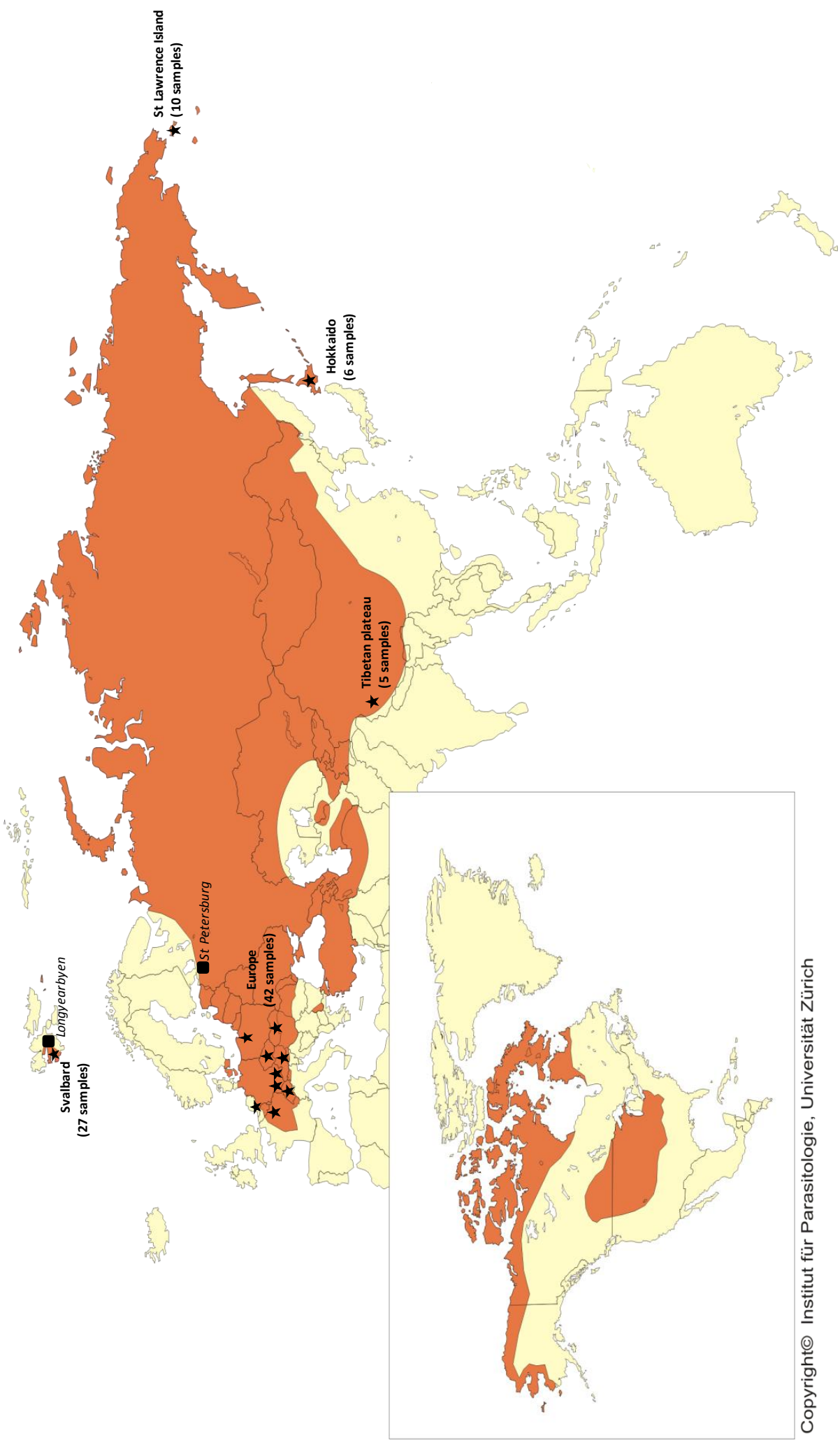

$218 \quad$ Fig. 1 


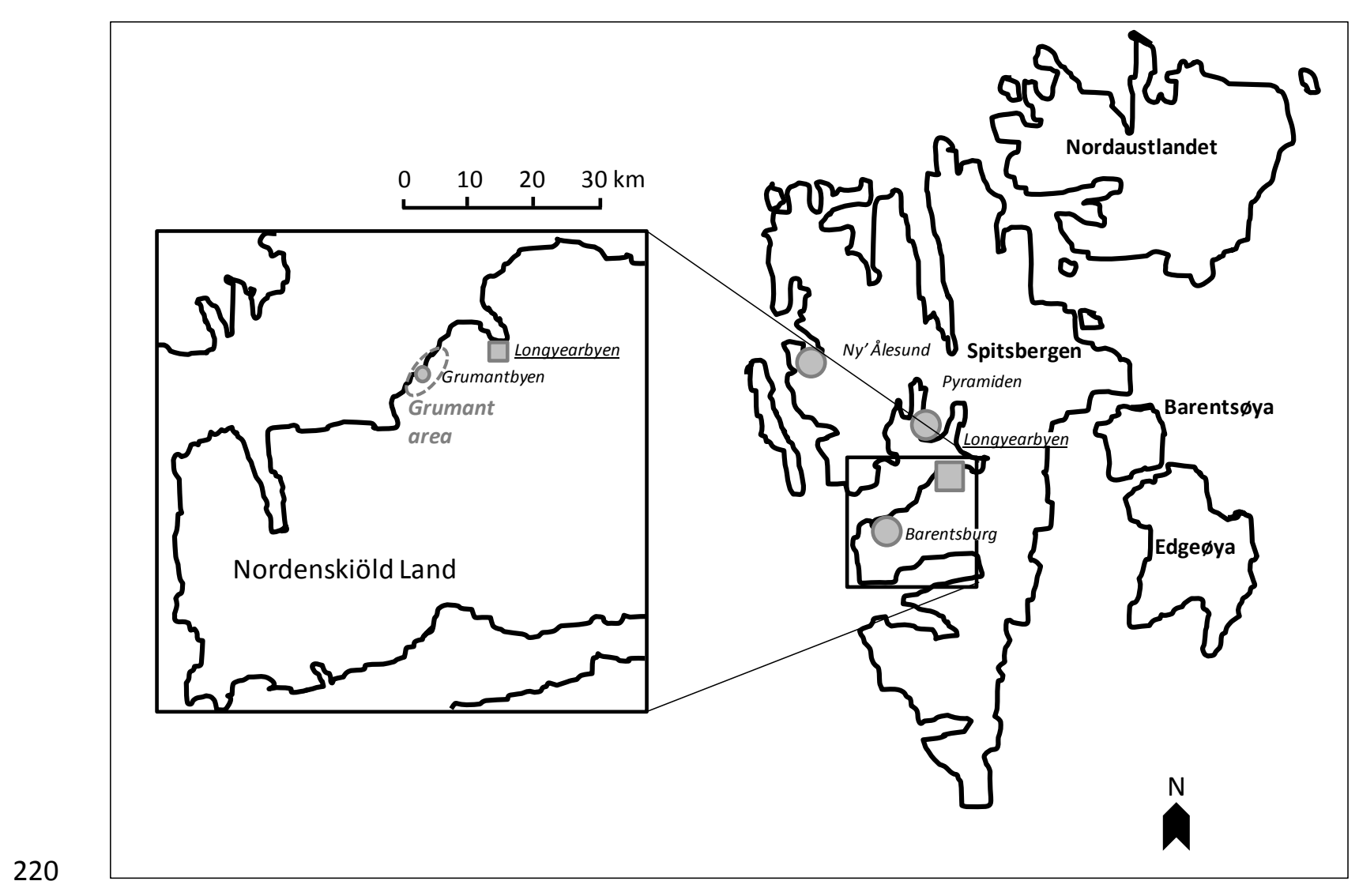

221 Fig. 2

222

223

224 


\section{Genetic distance}

(b)

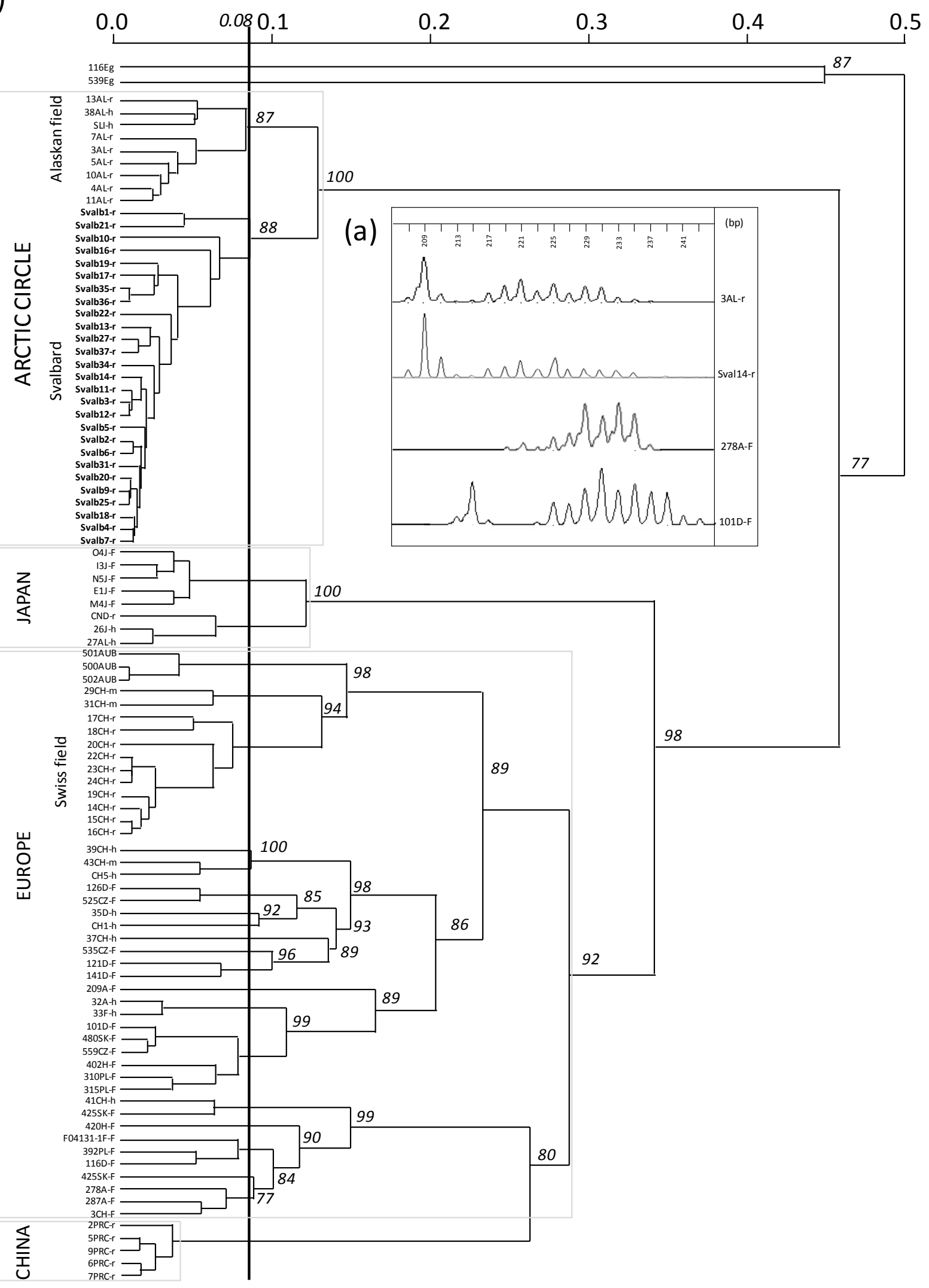

Fig. 3 
Bart, J.M., Knapp, J., Gottstein, B., El-Garch, F., Giraudoux, P., Glowatzki, M.L., Berthoud, H., Maillard, S., Piarroux, R., 2006. EmsB, a tandem repeated multi-loci microsatellite, new tool to investigate the genetic diversity of Echinococcus multilocularis. Infect Genet Evol 6, 390-400.

Eckert, J., Deplazes, P., Kern, P., 2011. Alveolar echinococcosis (Echinococcus multilocularis) and neotropical forms of echinococcosis (Echinococcosis vogeli and Echinococcus oligarthrus). In: Brown, D., Palmer, S., Torgerson, P. R., Soulsby, E. J. L. (Eds.), Zoonoses 2nd Edition. Oxford University Press, Oxford, pp. 668-699.

Fuglei, E., Stien, A., Yoccoz, N.G., Ims, R.A., Eide, N.E., Prestrud, P., Deplazes, P., Oksanen, A., 2008. Spatial distribution of Echinococcus multilocularis, Svalbard, Norway. Emerg Infect Dis 14, 73-75.

Haag, K.L., Zaha, A., Araújo, A.M., Gottstein, B., 1997. Reduced genetic variability within coding and non-coding regions of the Echinococcus multilocularis genome. Parasitology 115 ( Pt 5), 521-529.

Hall, T.A., 1999. BioEdit a user-frendly biological sequence alignment editor and analysis program for Windows 95/98/NT. Nucl Acids Symp Ser. 41, 95-98.

Henttonen, H., Fuglei, E., Gower, C.N., Haukisalmi, V., Ims, R.A., Niemimaa, J., Yoccoz, N.G., 2001. Echinococcus multilocularis on Svalbard: introduction of an intermediate host has enabled the local life-cycle. Parasitology 123, 547-552.

Knapp, J., Bart, J.M., Giraudoux, P., Glowatzki, M.L., Breyer, I., Raoul, F., Deplazes, P., Duscher, G., Martinek, K., Dubinsky, P., Guislain, M.H., Cliquet, F., Romig, T., Malczewski, A., Gottstein, B., Piarroux, R., 2009. Genetic diversity of the cestode Echinococcus multilocularis in red foxes at a continental scale in Europe. PLoS Negl Trop Dis 3, e452.

Knapp, J., Bart, J.M., Glowatzki, M.L., Ito, A., Gerard, S., Maillard, S., Piarroux, R., Gottstein, B., 2007. Assessment of use of microsatellite polymorphism analysis for improving spatial distribution tracking of Echinococcus multilocularis. J Clin Microbiol 45, 2943-2950. diversity of Echinococcus multilocularis on a local scale. Infect Genet Evol 8, 367-373.

Norén, K., Carmichael, L., Dalén, L., Hersteinsson, P., G, S., Fuglei, E., Kapel, C., Menyushina, I., patterns and processes. Oikos 000, 1-13.

Osterman Lind, E., Juremalm, M., Christensson, D., Widgren, S., Hallgren, G., Ågren, E.O., Uhlhorn, H., 
Rausch, R.L., 1995. Life cycle patterns and geographic distribution of Echinococcus species, In:

265 Thompson RCA, Lymbery AJ. Echinococcus and hydatid disease. Oxon (UK): CAB International ed, pp.

266 89-134.

267 Saarma, U., Jogisalu, I., Moks, E., Varcasia, A., Lavikainen, A., Oksanen, A., Simsek, S., Andresiuk, V., 268 Denegri, G., Gonzalez, L., Ferre, E., Garate, T., Rinaldi, L., Maravilla, P., 2009. A novel phylogeny for 269 the genus Echinococcus, based on nuclear data, challenges relationships based on mitochondrial 270 evidence. Parasitology 136, 317-328.

271 Stieger, C., Hegglin, D., Schwarzenbach, G., Mathis, A., Deplazes, P., 2002. Spatial and temporal 272 aspects of urban transmission of Echinococcus multilocularis. Parasitology 124, 631-640.

273 Stien, A., Voutilainen, L., Haukisalmi, V., Fuglei, E., Mørk, T., Yoccoz, N.G., Ims, R.A., Henttonen, H., 274 2010. Intestinal parasites of the Arctic fox in relation to the abundance and distribution of 275 intermediate hosts. Parasitology 137, 149-157.

276 Vuitton, D., Zhou, H., Bresson-Hadni, S., Wang, Q., Piarroux, M., Raoul, F., Giraudoux, P., 2003.

277 Epidemiology of alveolar echinococcosis with particular reference to China and Europe. Parasitology.

278 127, s87-107. 